Щипанський П. В., к.військ.н., професор;

Корецький А. А., к.військ.н., с.н.с.;

Капосльоз Г. В., к.психол.н., с.н.с.;

Зайцев М. М., к.ю.н.

Національний університет оборони України імені Івана Черняховського, Київ

\title{
Організація підготовки докторів філософії у країнах Свропейського союзу та Україні: стан, тенденції, перспективи
}

Резюме. У статті представлено аналіз стану організації підготовки здобувачів вищої освіти ступеня доктора філософії у країнах Європейського союзу та Україні, визначено тенденції та перспективи розвитку організації підготовки здобувачів ступеня доктора філософії.

Ключові слова: доктор філософії; здобуття вищої освіти; європейський досвід; організація підготовки.

Постановка проблеми. Прагнення України інтегруватися у європейський простір вищої освіти, увійти до Свроатлантичного союзу (НАТО) формують нові вимоги до компетентності науково-педагогічних працівників (НПП), а також вимагають зміни стандартів підготовки фахівців вищої кваліфікації - докторів філософії.

На сьогодні, відповідно до положень державних та відомчих нормативно-правових актів: Закону України "Про вищу освіту" [1], постанови Кабінету Міністрів України "Про затвердження Порядку підготовки здобувачів вищої освіти ступеня доктора філософії та доктора наук у вищих навчальних закладах (наукових установах)" [2] та наказу Міністерства оборони України "Про затвердження Особливостей підготовки здобувачів вищої освіти ступеня доктора філософії та доктора наук у вищих військових навчальних закладах (науково-дослідних установах) Міністерства оборони України" [3] особи офіцерського складу (працівники ЗС України) мають право здобувати вищу освіту ступеня доктора філософії в ад'юнктурі та поза ад'юнктурою у вищому військовому навчальному закладі (ВВН3), науковій установі (НУ) 3С України, або в аспірантурі інших закладів вищої освіти (ЗВО) та НУ України. Однак під час реалізації цього права виникають певні проблеми щодо реалізації положень зазначених нормативно-правових документів як в Україні, так і в Збройних Силах України, тому аналіз стану й тенденцій і перспектив розвитку підготовки докторів філософії у країнах Європейського союзу, має важливе значення для організації підготовки цієї категорії здобувачів вищої освіти в Україні, зокрема, удосконалення системи підготовки наукових i науково-педагогічних кадрів для Збройних Сил України.

Аналіз останніх досліджень i публікацій. До введення в дію зазначених нормативно-правових актів здійснено обговорення, проте і до сьогодні точиться дискусія щодо способів реалізації вже прийнятих положень. Як правило у наукових публікаціях розглядаються окремі питання організації підготовки здобувачів вищої освіти ступеня доктора філософії [4-7]. Аналіз стану, тенденцій та перспектив організації підготовки докторів філософії потребує додаткового вивчення.

Мета статті. Проаналізувати стан, визначити тенденції та перспективи розвитку організації підготовки здобувачів ступеня доктора філософії в країнах Європейського союзу та Україні.

Виклад основного матеріалу. У політичних і громадських колах $\mathrm{CC}$ існує думка: оскільки людські ресурси $\epsilon$ найважливішим багатством, політика у сфері освіти має бути спрямована на реалізацію трьох стратегічних цілей - підвищення якості

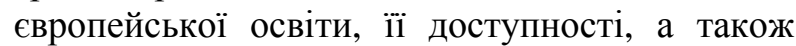
відкритості для всього світу. Організація докторської $(\mathrm{PhD})$ освіти в університетах європейських країн має такі особливості:

1. Існує три підходи до організації підготовки докторів філософії:

індивідуальні програми - виконуються під безпосереднім керівництвом і контролем наукового керівника (у Німеччині традиційно відсутні обов'язкові освітні курси і все навчання здійснюється у процесі спілкування 3 науковим керівником). На особливу увагу 
заслуговують програми, відомі як “професійні докторські”, або, як їх іноді називають, “практико-орієнтовані докторські”. Ці програми передбачають як виконання наукових досліджень, так і професійну практику. Така практика отримала розвиток у Великобританії [8], де число професійних докторів швидко зростає. Для забезпечення однаково високого рівня якості професійні доктора мають відповідати тим самим основним стандартам, що й “традиційні $\mathrm{PhD}$ ”;

структуровані програми - передбачають два види підготовки: обов'язкове навчання i дослідницьку роботу (у Швеції навчання в аспірантурі здійснюється відповідно до ECTS і включає 240 кредитів, 3 яких половина відводиться на підготовку дисертації);

організовані дослідницькі групи або докторські иколи (монодисциплінарні та мультидисциплінарні, керовані централізовано (Фінляндія, Франція), а також в кооперації 3 науково-дослідними інститутами або консолідованими організаціями (Німеччина)).

Деякі європейські країни правила організації докторських програм встановили на національному рівні, і університети слідують цим вимогам. У ряді європейських країн університетська автономія набагато ширше, i правила організації докторських програм $є$ прерогативою університетів.

2. Відмінності у статусі докторантів:

у Великобританії докторанти за статусом прирівняні до студентів (здобувачів вищої освіти). Вони отримують зовнішні гранти або працюють за контрактами над виконанням дослідницьких проектів. Їхнє навчання не оплачується університетами, а навпаки, приносить університетам гроші й авторитет, а самим докторантам - можливість користуватися повною мірою академічної свободою і правами споживачів послуг, що надаються університетами;

у Норвегї докторанти за статусом прирівняні до наукових співробітників, яким платять зарплату. Вони мають різні контракти 3 університетами як співробітники та здобувачі, у яких чітко прописані всі їх права та обов' язки.

3. Для стандартизації вимог до здобувачів вищої освіти широко використовуються “дублінські дескриптори” (характерні ознаки, вимоги), схвалені на конференції міністрів у Бергені. Для докторської освіти дублінські дескриптори визначають, що здобувач докторського ступеня мусить: продемонструвати системне розуміння своєї галузі знань і предмета дослідження;

продемонструвати здатність задумати проект, реалізувати його, адаптувати реальний процес дослідження до сучасних академічних вимог;

зробити шляхом проведення оригінального наукового дослідження певний внесок у розширення своєї галузі знань, опублікувавши отримані результати в національних i міжнародних наукових виданнях;

бути здатним до критичного аналізу, оцінки та синтезу нових і складних ідей;

бути здатним спілкуватися 3 колегами, 3 академічним і професійним співтовариством у своїй галузі знань;

бути перспективним із дослідницького i професійного погляду для технологічного, соціального i культурного розвитку знань суспільства.

4. Спостерігається низка негативних тенденцій, що впливають на підготовку наукових кадрів вищої кваліфікації:

відзначається зменшення інтересу студентів до отримання наукового ступеня $\mathrm{PhD}$ у Європі;

відтік наукових кадрів у США, де вченим, у тому числі й молодим, надаються кращі умови для роботи, включаючи свободу здійснювати наукові дослідження за обраним напрямом, можливості доступу до новітньої лабораторно-експериментальній бази наукових центрів, привабливіші перспективи кар'єрного росту i матеріального благополуччя. За оцінками німецького уряду в США 3 Німеччини виїхало близько $15 \%$ молодих вчених. Проведені опитування свідчать, що понад $70 \%$ європейців, які виїхали на навчання до США і захистили там докторські дисертації, не планують повертатися до Свропи;

випускники докторських програм не схильні будувати кар'єру викладача університету чи вченого, особливо якщо йдеться про фундаментальну науку. У Франції, захистивши дисертацію, докторанти полишають науку заради прибутковішої роботи.

5. Урядами країн Свропи передбачаються конкретні кроки для зміни негативних тенденцій:

для компенсації “витоку мізків" Європейською Комісією запроваджено програму ERASMUS MUNDUS, спрямовану на 
надання можливостей студентам з інших країн навчатися в європейських університетах [9];

в університетах Німеччини засновано “професуру для юніорів" і навіть розглядалося питання скасування обов'язкової умови, наявність докторського ступеня $(\mathrm{PhD})$ для обіймання посади завідувача кафедри [9];

розширенню дослідницького досвіду докторантів та можливостей розвитку їх подальшої кар'єри у Європі має сприяти мобільність студентів (у різних формах: міжуніверситетські докторські програми, міжнародне співробітництво дослідницьких груп або індивідуальні стажування за кордоном) як складова частина докторських програм. Проте нині мобільність студентів, яка забезпечується програмою ERASMUS MUNDUS, дає змогу щорічно залучати близько 120 тисяч нових студентів (менше $1 \%$ загального складу). Загальна чисельність "мобільних" студентів у Європі ледве сягає 1 млн осіб. Ще менші результати мобільності викладачів ВНЗ за програмою "Леонардо да Вінчі”. Перешкодами для мобільності $\epsilon$ чинники законодавчого, адміністративного, фінансового i культурного характеру, тому вона в Свропі доволі обмежена [10].

6. Останніми роками перед європейськими університетами постало нове завдання - моніторинг подальшої кар'єри випускників докторських програм, яким було присуджено вчений ступінь доктора філософії. Метою цього кроку є оцінювання значення i впливу різних нововведень і реформ на якість докторських програм, виявлення їх сильних i слабких сторін, а також сфери застосування набутих у докторантурі знань і навичок.

Стан організації підготовки здобувачів ступеня доктора філософії в Україні характеризується зміною поглядів щодо підготовки здобувачів вищої освіти ступеня доктора філософії на третьому (освітньонауковому) рівні вищої освіти. Україна підтвердила своє прагнення інтегруватися в європейський освітній простір. Проте під час реалізації положень нормативно-правових актів виникають проблеми адаптації сфери освіти і науки України до умов ринкової економіки. Це цілком зрозуміло, оскільки в основу існуючої системи підготовки та атестації наукових i науково-педагогічних кадрів було закладено принципи радянської системи підготовки кадрового потенціалу науки і вищої освіти, в яких ринкові аспекти (оплата праці здобувачів, що беруть участь у наукових дослідженнях, їх навчання за рахунок коштів виділених на проведення наукових досліджень, впровадження результатів наукових досліджень здобувачів з їх переходом у виробничий сектор тощо) не могли бути присутніми, окрім того:

у період кризових політичних i економічних умов у нашій країні можливості організації інноваційних освітніх структур, націлених на міждисциплінарну підготовку наукових і науково-педагогічних кадрів, були упущені, а на сьогодні недостатньо вивчені шляхи іх організації та забезпечення ефективного функціонування;

недостатньо зрозумілі можливості міждисциплінарної та міжсекторальної мобільності аспірантів і докторантів, хоча на практиці елементи такої мобільності присутні при проведенні спільних наукових досліджень, організації стажувань аспірантів, проведенні спільних семінарів i конференцій, в консультативній практиці тощо;

не вирішено питання порядку атестації докторів філософії, зокрема не уточнено вимоги, що до них висуваються;

відсутні методики визначення перспективних напрямів їх кар'єрного зростання.

Діюча, на цей час в Україні, система атестації наукових кадрів передбачає триступеневий процес експертизи дисертацій. Визначення особистого внеску здобувача в науку здійснюється на першому етапі під час попереднього захисту в науковому колективі, де безпосередньо виконувалась робота. Ця стадія $\epsilon$ вирішальною при визначенні актуальності теми дисертації, iï зв'язку 3 планами наукових досліджень, а також загального рівня теоретичної підготовки здобувача, його наукової зрілості. Другий і основний етап - захист дисертації на засіданні спеціалізованої вченої ради. Тут дається аргументований висновок фахівців щодо новизни, достовірності, наукової та практичної значущості результатів дисертації. $\boldsymbol{H a}$ mpemboмy emani експертна рада Міністерства освіти i науки України контролює відповідність вимог до наукової та практичної цінності, які висуваються до дисертацій спеціалізованими радами.

Головна проблема існуючої системи атестації - багаторівнева відповідальність, яка побудована нераціонально як 3 організаційної (розподіл відповідальності між установами та організаціями (радами) не виправдано підвищує формальні вимоги до дисертаційної роботи та створює коло “пов' язаних” осіб), так 
і 3 економічної - веде до невиправданого дублювання експертних робіт, поглядів. На нашу думку, необхідно прибрати дублювання функцій контролю змісту дисертацій, і в цій частині, уточнити функції експертної ради, одночасно розширивши повноваження та відповідальність проектних груп та їх керівників (гарантів спеціальності).

Різноманітність окреслених підходів до організації докторських програм у країнах Європейського союзу та Україні може розглядатися, 3 одного боку, як перевага європейського та українського освітнього i наукового простору, а, 3 іншого боку, як недолік, що веде до фрагментації докторської освіти і перешкоджає створенню та підтримці адекватного дослідницького середовища.

Слід визнати, що політика Свропейської асоціації університетів поки спрямована на збереження різноманітності систем організації докторського освіти. Така різноманітність $є$ відображенням зростаючого різноманіття в європейській вищій освіті, де вищі навчальні заклади можуть самостійно формувати власні місії і профілі, а, отже, і власні пріоритети 3 погляду програмних i дослідницьких уподобань. Проте визнається, що всі кваліфікації, визначені як докторські (незалежно від їх типу), мають базуватися на обов'язкових процесах і результатах.

Підготовка докторів філософії в Європейських країнах, пройшовши довгий шлях еволюції, який призвів до виникнення національних особливостей систем вищої освіти різних країн, на сучасному історичному етапі має тенденцію до стандартизації певних аспектів. Основні погляди європейські фахівців [11] щодо цілей стандартизації вищої освіти та переваг у разі їх досягнення наведено у табл. 1.

Таблиця 1

Цілі стандартизації вищої освіти та очікувані результати

\begin{tabular}{|c|c|c|c|}
\hline $\begin{array}{l}\text { № } \\
\text { 3/II }\end{array}$ & Цілі стандартизації & Заходи стандартизації & $\begin{array}{c}\text { Очікувані від } \\
\text { стандартизації переваги }\end{array}$ \\
\hline 1 & \begin{tabular}{llr}
\multicolumn{2}{c}{ Визначення єдиних } & вимог \\
стосовно того, що & здобувач \\
ступеня вищої освіти & повинен \\
знати, розуміти та & вміти \\
(результатів навчання) &
\end{tabular} & $\begin{array}{l}\text { Впровадження загальної рамкової } \\
\text { системи кваліфікацій (overarching frame } \\
\text { work for qualifications) та відповідних } \\
\text { національних paмкових систем } \\
\text { кваліфікацій (national qualifications frame } \\
\text { works). } \\
\text { Впровадження додатка до диплома } \\
\text { єдиного європейського зразка } \\
\end{array}$ & $\begin{array}{l}\text { Досягнення прозорості та } \\
\text { сумісності ступеню вищої } \\
\text { освіти. } \\
\text { Академічна } \\
\text { докторантів. }\end{array}$ \\
\hline 2 & \begin{tabular}{|lr|}
\multicolumn{2}{|c}{ Забезпечення язку між } \\
навчальним навантаженням в \\
рамках освітньої програми \\
результатами навчання
\end{tabular} & $\begin{array}{l}\text { Розроблення навчальних планів. } \\
\text { Впровадження Європейської кредитної } \\
\text { трансферно-накопичувальної } \\
\text { (ЄКТС) } \\
\end{array}$ & $\begin{array}{l}\text { Мобільність професорсько- } \\
\text { викладацького складу. } \\
\text { Організація } \\
\text { кооперації. } \\
\text { Піжвузівської } \\
\end{array}$ \\
\hline 3 & \begin{tabular}{|c|}
\multicolumn{2}{c|}{ Створення кращих можливостей } \\
щодо доступу до освітніх послуг, \\
особистого $\quad$ зростання як \\
студентів, так і викладачів
\end{tabular} & $\begin{array}{l}\text { Розроблення програм мобільності та } \\
\text { спільних програм навчання, підготовки } \\
\text { та досліджень }\end{array}$ & \begin{tabular}{llr} 
Продвищення & \multicolumn{2}{c}{ зайнятост1 } \\
громадян & Свропи & та \\
конкурентоздатності & \\
європейської & системи & вищої
\end{tabular} \\
\hline 4 & \begin{tabular}{lr}
\multicolumn{1}{|c}{ Сприяння } & європейському \\
співробітництву у & забезпеченні \\
якості вищої освіти. & \\
\end{tabular} & $\begin{array}{l}\text { Розроблення спільних критеріїв та } \\
\text { методик оцінювання }\end{array}$ & \\
\hline
\end{tabular}

Таким чином, досягнення цілей стандартизації вищої освіти дасть змогу забезпечити розвиток здобувачів вищої освіти та дослідників їх зайнятість на теренах Європи шляхом підвищення якості вищої освіти та наукових досліджень, усунення перешкод для їх вільного переміщення в межах Європейського союзу.

Гармонізація

підготовки

$3 a$ бакалаврськими та магістерськими програмами відповідно до трирічних і дворічних циклів була основною метою підписання Болонської декларації 1999 року. На той час докторська підготовка у декларації не згадувалася. “Третій цикл” вищої освіти був включений до Болонських декларацій у 2003 році, на зустрічі міністрів вищої освіти у Берліні. Міністри зійшлися на тому, що:

має бути

посилена мультидисциплінарність “третього циклу”; слід заохочувати спільне присудження університетами різних країн вчених ступенів (jointdegrees);

багатофункціональні навички, що уможливлюють фахову мобільність (transferableskills), мають увійти до програм докторської освіти й підготувати докторантів для працевлаштування поза академічним світом.

Бергенська конференція міністрів, що відбулася у травні 2005 року, у своїх висновках наголосила на важливості 
узгодження докторських програм в Свропі на основі рекомендацій, викладених у загальновідомих 10-ти Зальцбурзьких принципах. Вважаємо за необхідне наголосити на першому: “Отримання додаткових знань у ході виконання оригінальних досліджень (ключовою складовою навчання за докторськими програмами є отримання знань через проведення оригінальних досліджень). Підготовка докторів має задовольняти вимогам ринку праці (визнається, що докторські студії мають більше відповідати потребам ринку робочої сили, який $\epsilon$ значно ширшим за академічну сферу). Лише перша теза принципу знайшла загальне відображення у Законі України "Про наукову i науково-технічну діяльність”. Проблеми впливу ринку праці на підготовку докторів філософії в нашій країні не досліджені, не вирішені питання організації їх працевлаштування (у провідних Свропейських країнах значна частинна (30-50 \%) випускників докторантур працевлаштовуються у промисловому секторі).

Стосовно низки проблем застосування інструментів Болонської декларації до докторських програм досі тривають дискусії. Взаємне визнання кваліфікацій в рамках Болонського процесу засновано на загальній модульній структурі навчання, коли кваліфікація випускників бакалаврату та магістратури вимірюється в рамках загальної для всіх ВН3 системи кредитів (ECTS), яка сприяє розвитку мобільності студентів. При перенесенні цієї практики на докторські програми виникають певні складнощі:

3 одного боку, самостійний характер роботи над дисертацією забезпечує мобільність докторантів (терміни i час їх перебування в іншому університеті фактично визначаються тільки особистими графіками i згодою керівника (спів керівників) науково-дослідних проектів). Проте, виходячи 3 того, що докторанти мають виробляти нове знання - нові продукти та процеси в рамках дослідницьких проектів, то виконання дисертаційного дослідження має бути основним у докторських програмах, а вимірювати “навчальне навантаження" 3 написання докторської дисертації в системі кредитів ECTS недоцільно;

3 іншого боку, оскільки зміст докторської дисертації має бути якомога менш стандартним, то освітня складова, що забезпечує проведення дисертаційного дослідження та влаштування на ринку праці (за результатами проведеного дослідження) також має бути нестандартною. Виникає запитання, яким чином зараховувати кредити ECTS за опанування освітньою складовою програми в іншому навчальному закладі (НУ).

На цьому фоні, вже сьогодні можна говорити про тенденції щодо збільшення в структурі докторських програм навчальних курсів і тренінгів. Вочевидь це пов'язано 3 вимогами європейського ринку - готувати випускників цих програм не тільки до академічної, але і до прикладної спеціалізації та професійної кар'єри в реальних секторах економіки.

Важливо відзначити, що за даними соціологічних опитувань переважна більшість європейських докторантів вважає додаткові тренінги під час навчання необхідними i корисними для подальшої роботи. Найбільшою популярністю у докторантів користуються такі тренінги, як “управління проектами”, “складання технічних завдань”, "написання проектних заявок”, “право інтелектуальної власності”.

Останнім часом європейські університети, як основні організатори докторської освіти, стикаються 3 новими викликами пов'язаними 3 підготовкою докторів філософії:

зростаюча частка фундаментальних та прикладних наукових досліджень, які проводяться на “стику наук" потребує розширення міждисциплінарних перспектив при навчанні на докторських програмах;

зростаюче усвідомлення важливості впровадження наукових результатів для природничих i технічних наук потребує розширення співпраці 3 різними секторами економіки, розроблення нових форм комунікації та адміністративної підтримки;

зростаючий суспільний інтерес до науки ऑiі комерціоналізація вимагають від учених приділяти більше часу інформуванню про результати отриманих наукових досліджень, а також про їх громадське та економічне значення, з' являються нові вимоги до навичок комунікацій із 3MI [12] та виробництвом;

через різні підходи до наукового керівництва, що припускають різну ступінь відповідальності наукового керівника, контролю якості його роботи, обсягу зобов'язань виникає питання про контроль якості опанування освітньою складовою та проведення наукових досліджень здобувачем;

нові потреби ринку праці, що динамічно розвивається, стали поштовхом формування інноваційних докторських 
програм. Працевлаштування докторантів усередині та поза академічних інститутів, індивідуальні та соціальні потреби в освіті та навчанні протягом усього життя стало каталізатором розроблення нових докторських програм, які $\epsilon$ результатом співпраці між університетами та промисловістю.

Очевидно, що адекватне реагування на виклики, які постають перед системою підготовки докторів філософії є перспективами ii розвитку. У цих умовах визначені тенденції об'єднання зусиль європейських країн задля створення загальноєвропейського науковоосвітнього простору і прагнення ввести певні рамки стандартизації у підготовку наукових i науково-педагогічних кадрів вищої кваліфікації в межах Болонського процесу мають сприяти реагуванню на зазначені виклики. Тому вироблення загальної структури, чітко визначених правил прийому до докторантури, організації наукового керівництва та контролю за ходом реалізації докторських програм, проведення іспитів, оцінки виконаних досліджень та захисту дисертацій у правових i нормативних документах, прийнятих на вищих рівнях влади, $є$ надзвичайно актуальним та інноваційним завданням як для університетів Європи так і України.

\section{Висновки:}

1. Стан організації докторських програм характеризується різними підходами щодо організації підготовки, визначенням статусу докторантів $(\mathrm{PhD})$ в країнах Європейського союзу. Окрім того, різнорідність переліків наукових дисциплін (відмінність методології, наукового інструментарію, методів аналізу тощо) значно впливає на організацію докторських програм в університетах у межах однієї країни.

2. Серед тенденцій організації підготовки докторів філософії доцільно виділити:

збереження різноманітності систем організації докторської освіти, забезпечення права вищих навчальних закладів самостійно формувати власні місії та профілі, а отже, i власні пріоритети 3 погляду програмних i дослідницьких уподобань;

стандартизація вищої освіти у частині забезпечення розвитку здобувачів вищої освіти та дослідників їх зайнятості на теренах Свропи чи України відповідно;

збільшення в структурі докторських програм спеціалізованих навчальних курсів i тренінгів.

3. Перспективами розвитку систем підготовки докторів філософії є: розширення

міждисциплінарних перспектив при навчанні на докторських програмах;

розроблення нових форм комунікації та адміністративної підтримки докторських програм;

задоволення вимог ринку праці щодо навичок докторів філософії в комунікації із ЗМІ та виробництвом;

удосконалення та стандартизація контролю якості опанування освітньою складовою та проведення наукових досліджень здобувачем вищої освіти;

розроблення нових докторських програм, які $\epsilon$ результатом співпраці між університетами та промисловістю.

\section{СПИСОК ВИКОРИСТАНИХ ДЖЕРЕЛ}

1. Закон України від 01.07.2014 № 1556-VII “Про вищу освіту" (зі змінами) / Відомості Верховної Ради України від 19.09.2014. - 2014, № 37-38, С. 2716 , ст. 2004.

2. Постанова Кабінету Міністрів України від 23 березня 2016 року № 261 “Порядок підготовки здобувачів вищої освіти ступеня доктора філософії та доктора наук у вищих навчальних закладах (наукових установах)" / Офіційний вісник України від 19.04.2016. - 2016, № 29, С. 13, ст. 1164, код акта 81513/2016.

3. Наказ Міністерства оборони України "Про затвердження Особливостей підготовки здобувачів вищої освіти ступеня доктора філософії та доктора наук у вищих військових навчальних закладах (науково-дослідних установах) Міністерства оборони України $\square$ від 24.02.2017 № 115 .

4. Бахрушин В. Зауваження та пропозиції щодо проекту положення про порядок підготовки фахівців ступеня доктора філософії та доктора наук в аспірантурі (ад'юнктурі) та докторантурі вищих навчальних закладів (наукових установ) [Електронний ресурс] / В. Бахрушин // Освітня політика : портал громадських експертів. - 2015. - Режим доступу : http://education-ua.org/ua/draftregulations/358-

5. Докторські програми в Європі та Україні: Матеріали міжнар. конф. "Впровадження принципів третього циклу вищої освіти Європейського простору в Україні” / НаУКМА; наук. ред., упоряд. В. Моринець. - К.: Унів. Видво ПУЛЬСАРИ, 2007. - 98 с.

6. Капосльоз Г. В. Досвід організації підготовки докторів філософії у деяких країнах Свропейського союзу / Г. В. Капосльоз, О. О. Рибчук // Військова освіта : Збірн. Наук. Праць. - К., 2016. - № 1(33). - С. 132-141.

7. Лук'яненко Д. Г. Про принципи та модель підготовки докторів філософії (PhD) в університеті [Електронний ресурс]: Презентація матеріалів робочої групи КНЕУ ім. В. Гетьмана / 
Лук’яненко Д. Г., Наливайко А. П., Антонюк Л. Л., Столярчук Я. М., Шевченко О. Л. - Published on Nov 12, 2014. - Режим доступу : http://www.slideshare.net/LukianenkoDG/ss-41450398 8. Taylor J. The United Kingdom / in [Sadlak J. Doctoral Studies and Qualifications in Europe and the United States: Status and Prospects. - Paris, UNESCO, 2004] - 302 p. Trends V: Universities shaping the European Higher Education Area. EUA.Socrates, 2007. - P.97. [Електронний ресурс] - Режим доступу: www.eua.be

9. Самарский А. Современные проблемы науки и образования Франции. Електронний ресурс] Режим доступу: mhtml:file://F: 15.03.2008
10. Відомості Євростату. [Електронний ресурс] Режим доступу: http://ec.europa.eu/eurostat /help/new-eurostat-website

11. The Bologna Declaration of 19 June 1999. [Електронний ресурс]. - Режим доступу : http://www. ehea. Info /Uploads/Declarations/ BOLOGNA_DECLARATION1.pdf

12. Diebesten Hoch schulenin Deutschland // Stern. 2001. - Heft 17. - S. 5768. Doctoral Programmers for European Knowledge Society. Report on the EUA Doctoral Programmers Project. 2004-2005. [Електронний ресурс]. - Режим доступу: www.ua.be

Стаття надійшла до редакції 08.08.2018

Щипанский П. В., к.воен.н., профессор;

Корецкий А. А., к.воен.н., с.н.с.;

Капослёз Г. В., к.психол.н., с.н.с.;

Зайцев Н. Н., к.ю.н.

Национальный университет обороны Украины имени Ивана Черняховского, Киев

Организация подготовки докторов философии в странах Европейского союза и Украине: состояние, тенденции, перспективы

Резюме. В статье представлен анализ состояния организации подготовки соискателей высшего образования степени доктора философии в странах Европейского союза и Украины, определены тенденции и перспективы развития организации подготовки соискателей степени доктора философии.

Ключевые слова: доктор философии; получение высшего образования; европейский опыт; организация подготовки.

\section{P. Shchypansky, PhD (Military), professor;}

\section{A. Koretsky, PhD (Military), senior researcher;}

G. Kaposlios PhD (Psychological), senior researcher;

N. Zajchev

National University of Defense of Ukraine named after Ivan Chernyakhovskyi, Kyiv

Organization of Doctors of Philosophy Preparation in the Countries of the European Union and Ukraine: state, trends, perspectives

Resume. The article presents the analysis of the state of the organization of the preparation of applicants for higher education in the degree of doctor of philosophy in the countries of the European Union and Ukraine, the trends and prospects for the development of the organization of the preparation of applicants for the degree of PhD.

Keywords: doctor of philosophy; higher education; European experience; organization of training. 